\title{
Comparative Assessment of Lectin Content in Leaves and Seeds of Two Species of Okra, Abelmoschus esculentus and Abelmoschus caillei
}

\author{
Abiodun A. Ajiboye ${ }^{1}$, Modinat A. Adekoya ${ }^{1}$, Abiodun I. Isiaka ${ }^{1, *}$, R. J. Komolafe ${ }^{1}$, A. O. David ${ }^{1}$, D. M. \\ Chukwuma $^{1}$, M. D. Ajiboye ${ }^{2}$ \\ ${ }^{1}$ Department of Plant Science and Biotechnology, Federal university Oye-Ekiti \\ Ekiti State, Nigeria \\ ${ }^{2}$ Department of Plant Biology, Osun State University, Osogbo \\ Osun State, Nigeria \\ *Corresponding author's email: abiodun.isiaka [AT] yahoo.com
}

\begin{abstract}
Lectin is a glycoprotein which possesses at least one non-catalyzing domain that specifically and reversibly binds to mono and oligosaccharides. The concentration of lectin in these two species of okra: (A.esculentus and A.caillei) were determined using the glycoprotein agglutinating property with carbohydrate coated surface (erythrocytes) that can easily bind with the lectin present in the two Okra species. The study revealed that A.esculentus has high lectin content in the leaves but the seeds are characterized with low lectin content. Comparatively, A.caillei has low lectin content in its leaves while high level of lectin content was found in its seeds. Protein were extracted and detected by Bradford methods. The data were subjected to analysis using SAS package (L.S.D) version 2009 and it showed that A.esculentus has high protein content in its seeds $(0.61 \mathrm{mg} / \mathrm{ml})$ when compared with leaves $(0.09 \mathrm{mg} / \mathrm{ml})$ of the same species. However, A.caillei has high level protein content in its leaves $(0.19 \mathrm{mg} / \mathrm{ml})$ as compared with the low protein content found in seeds $(0.58 \mathrm{mg} / \mathrm{ml})$. The research showed that the A.caillei has high level of lectin but low level of protein contents whereas; the A.esculentus has low level of protein but high level of lectin contents. It is recommended that further studies should be carried out on the genetic compatibility of the two species in order to explore a viable product that would have optimum level of lectin and high level of protein contents in specieof okra.
\end{abstract}

Keywords--- Lectin, Okra, Protein, leaves and seed

\section{INTRODUCTION}

Okra is an important vegetable crop in Nigeria. Its mucilaginous property aids in the consumption of bulky food materials while the fibre content makes it a candidate as a non-wood source of pulp, the major raw materials in paper industry. (Olayiwola et al. 2014).

A.caillei and A. esculentus L. Moench combined represent the second most important vegetable in the market after tomatoes. A.esculentuswas domesticated in West and Central Africa, but it is now widely cultivated throughout the tropics primarily for local consumption. A.esculentus is widely consumed as a fresh vegetable in both temperate and tropical countries. Although the seed pods are most often used (Camciuc et al., 1998), the mature seed is known to have superior nutritional quality. Rubatzky and Yamaguchi,(1997) reported that the seed is a rich source of protein and oil; contains cyclopropenoid fatty acids which cause some toxicity concerns and is used as a substitute for coffee in some countries.

Abelmoschus caillei occurs as an erect and stout herb that is often woody at the base. Its flowers are axillary, with their petals yellow to pink. It is consumed as a vegetable in a few ways, with young leaves consumed as spinach, young fruits consumed after being cooked or fried.

An understanding about plant lectins is that they are glycoprotein which posses at least one non-catalyzing domain that specifically and reversibly binds to mono and oligosaccharides. Their capability of specifically recognizing and binding to sugars of erythrocytes in vitro merits the term agglutinin; the process is termed agglutination (Ynalvez, et al, 2015).

It is now well established that many lectins are toxic, inflammatory, resistant to cooking and present in much of our food which sometimes cause food poisoning. The global pattern of varying prevalence of diseases such as coeliac disease, 
autoimmune diseases, rheumatoid arthritis, obesity, cardiovascular disease and insulin dependent diabetes mellitus, suggests that some dietary factor specific to plant foods could initiate these diseases. Of the food lectins, grain/cereal lectins, dairy lectins and legume lectins are the most common ones associated with aggravation of inflammatory and digestive diseases in the body (Hamid et al., 2013).

Therefore, this study aims at investigating the lectin and protein variability in two okra species obtained from National Centre for Genetic Resources and Biotechnology of Nigeria with a view to identify the species with favorable biochemical characters.

\section{MATERIALS AND METHODS}

\subsection{Chemical Reagents:}

Bradford reagent, Phosphate buffer saline (PBS), $2 \%$ erythrocytes.

\subsection{Collection of seed samples and the germination process}

The seeds used in this study were obtained from National Centre for Genetic Resources and Biotechnology, Ibadan, Nigeria.

Two seeds each of A.esculentus and A.caillei were sown in nine replicates. The soils in the plastic bucket were regularly watered to ensure that the soil was moist enough for plant growth.

After three days, there was emergence of radicle and plumule which serve as the evidence of germination of the seeds.

\subsection{Determination of protein}

\subsubsection{Preparation of crude extracts:}

Fresh leaves were dried in the oven at $45^{\circ} \mathrm{C}$. Dried leaves and seeds of each species were well labeled, and pulverized into powdery form using mortar and pestle.

\subsubsection{Protein determination in leaves:}

The leaves in each replicates were grounded into powdered form, $0.8 \mathrm{~g}$ of the samples in replicates were weighed and homogenized with $15 \mathrm{~mL}$ of a buffer solution $(0.1 \mathrm{M}, \mathrm{pH}=6.5)$ and stored in freezer for $12 \mathrm{~h}$. The samples were centrifuged at $4000 \mathrm{rpm}$ for $15 \mathrm{~min}$ and the supernatant were collected into a well labeled universal tubes.

\subsubsection{Protein determination via seeds:}

The seeds in each replicates were grounded into powdered form, $1.5 \mathrm{~g}$ of the grounded seeds were weighed and transfer to the well labeled universal tubes and $5 \mathrm{~mL}$ of the prepared buffer $(0.1 \mathrm{M}$ solution, $\mathrm{pH}=6.5)$ was added to each tubes and were left in the freezer overnight. The samples were transferred from the universal bottle to the plastic test tubes and then centrifuged at 4000rpm for 15 minutes. Supernatant were later decanted into the universal tubes.

\subsubsection{Determination of protein by Bradford method:}

$100 \mu \mathrm{L}$ of distilled water $\left(\mathrm{H}_{2} \mathrm{O}\right)$ was pippeted into a well labeled test tube with $500 \mu \mathrm{L}$ of BRADFORD reagent as blank. $100 \mu \mathrm{L}$ of the extracts in replicates were pippeted into small test tubes and $500 \mu \mathrm{L}$ of BRADFORD reagent were also added into the test tube containing each replicate. The replicates were then checked under Vis-Spectrophotometer @ 595 wavelengths.

\section{Assay of Hemagglutinating Activity:}

The agglutination of red blood cells by the crude extract was carried out.100 $\mu \mathrm{L}$ of phosphate buffered saline (PBS) was delivered sequentially into wells arranged in rows(each containing 12 wells) on a U-shaped microtitre plate. $100 \mu \mathrm{L}$ of the crude extract was added into first well to obtain a twofold dilution. A serial dilution was made by transferring $100 \mu \mathrm{L}$ of the diluted sample in a particular well into the next well containing $100 \mu \mathrm{Lof}(\mathrm{PBS})$.

Aliquots $(50 \mu \mathrm{L})$ of the $2 \%$ erythrocyte suspension were added to each well and the microtitre plates were left undisturbed for $1 \mathrm{~h}$.The titre value was taken as the reciprocal of the highest dilution of the extract causing visible hemagglutination. Specific activity is the number of hemagglutinating units per $\mathrm{mg}$ protein expressed as hemagglutinating units (Hv)/mg.Picture was taken after 1h: 30mins (John et al. 2007). 


\section{RESULTS}

\subsection{Protein variation between Abelmoschus esculentus and Abelmoschus caillei :}

Bluecolourationindicatesthepresenceofproteinineachreplicateswhen Bradford reagent was added to it (Bradford,1976).The protein variations are shown below in fig 1 and 2.

\subsection{Hemagglutination of the samples:}

After the supernatant of the samples was collected, they were tested for their hemagglutinating activity. The leaves and seeds extract of $A$. esculentus and A.caillei samples showed the ability to hemagglutinate human red blood cells (erythrocytes) The ability of these samples to hemagglutinate was determined by its ability to suspend red blood cells in a buffer, done through their ability to bind to two red blood cells and to form a lectin- erythrocyte-lectin matrix, leading to their clumping. When agglutination occurs, cross linked red blood cells form a network that prevents the red blood cells from sedimenting to the bottom of the well. They appeared like a carpet that covers the whole microtiter plate well. When there was no agglutination, the red blood cells sedimented and formed a button on the bottom of the well.

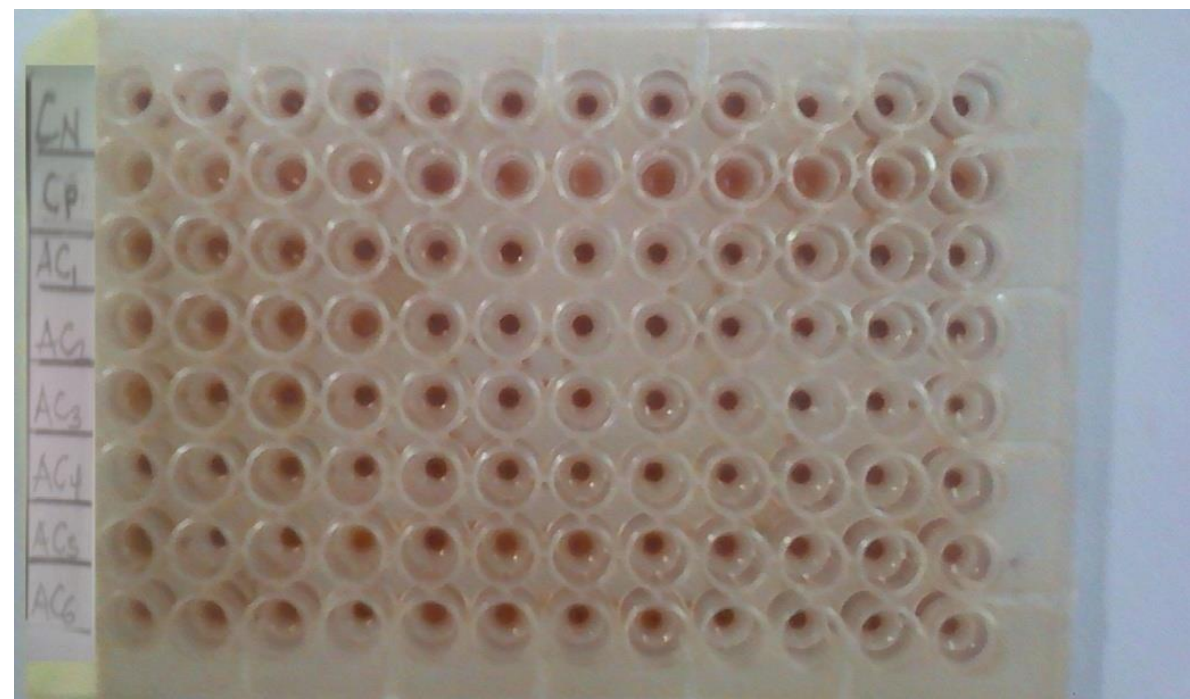

Plate 1: Hemagglutinating activity of lectin in affinity extracted from A.caillei: samples

Keys to plates: CN-Negative control

CP- Positive control

AC1- AC6: A.caillei:leave sample.

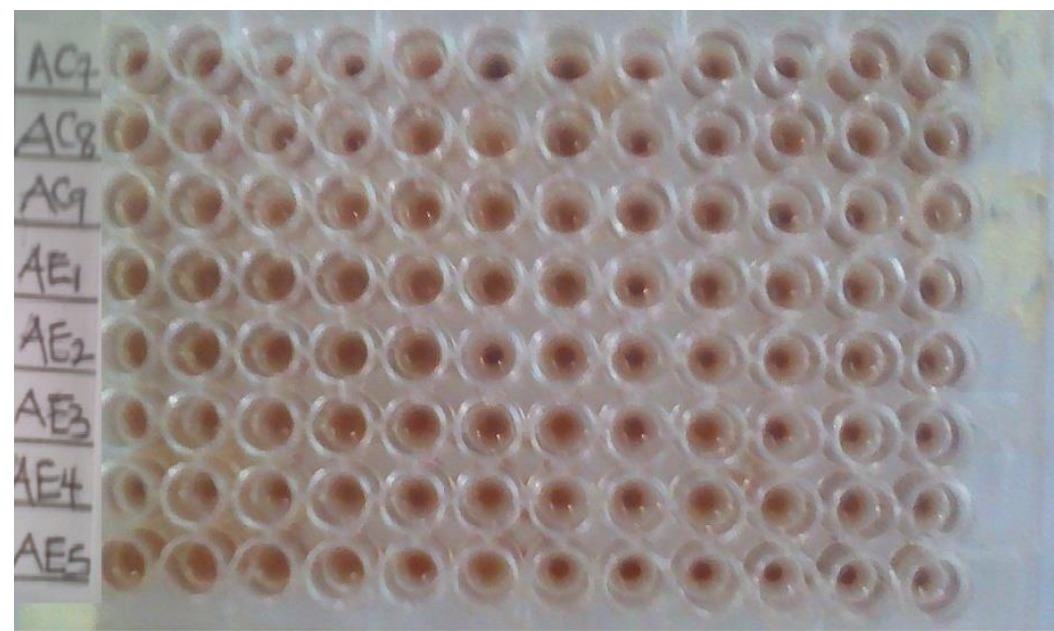

Plate 2: Hemagglutinating activity of lectin in affinity extracted from A.caillei:and 
A.esculentus:leaves

Key to plate:AC7-AC9:A.caillei:hemaglutinating leaves sample

AE1-AE5:A.esculentus:hemaglutinating leave sample

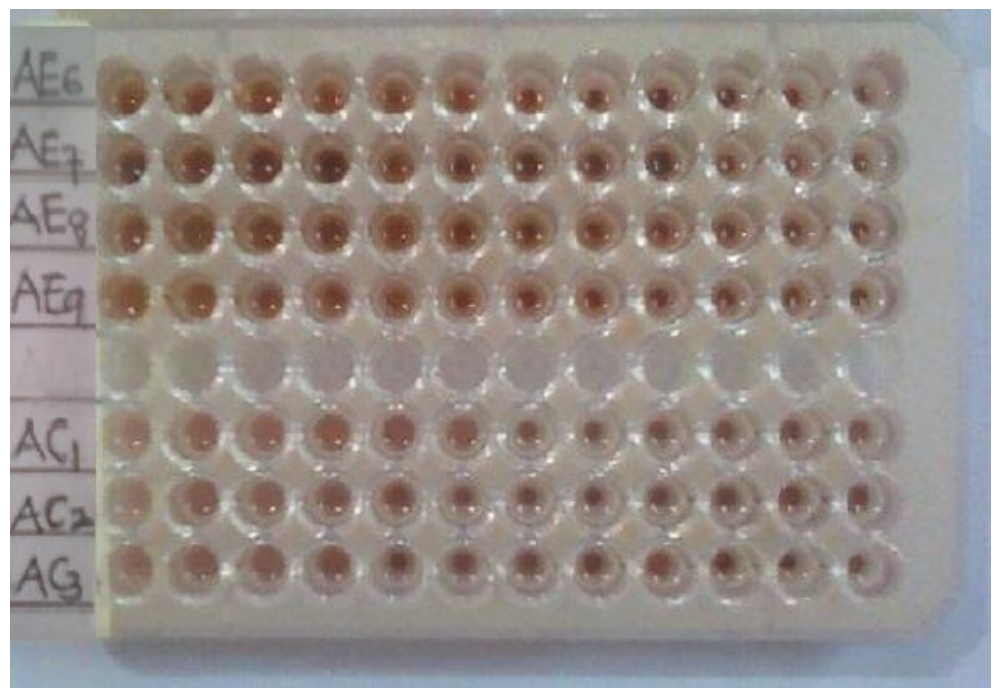

Plate 3: Hemagglutinating activity of lectin in affinity extracted from A.cailleiand A.esculentus

Key to plate:A.E6-AE9:A.esculentus:hemaglutinating leave sample

AC1-AC3:A.caillei:hemaglutinating seed sample

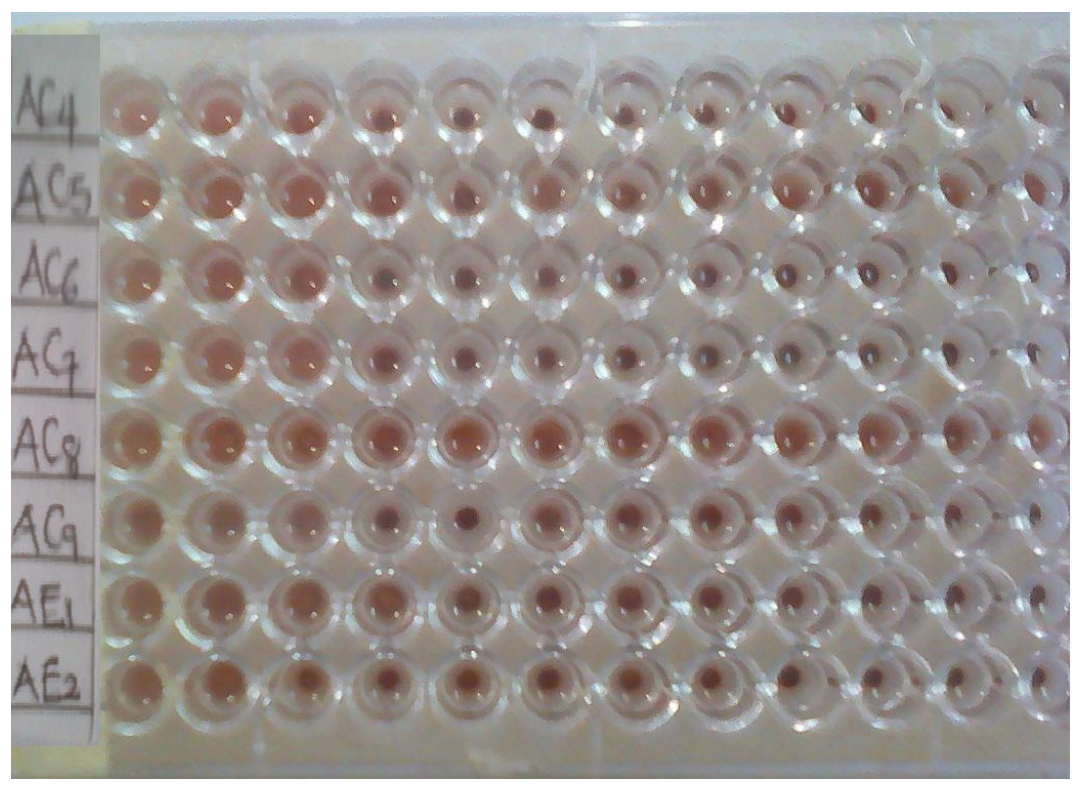

Plate 4: Hemagglutinating activity of lectin in affinity extracted from A.caillei and A.esculentus.

Key to plate:AC4-AC9: A.caillei:hemaglutinating seed sample

AE1-AE2: A.esculentus:hemaglutinating seed sample 


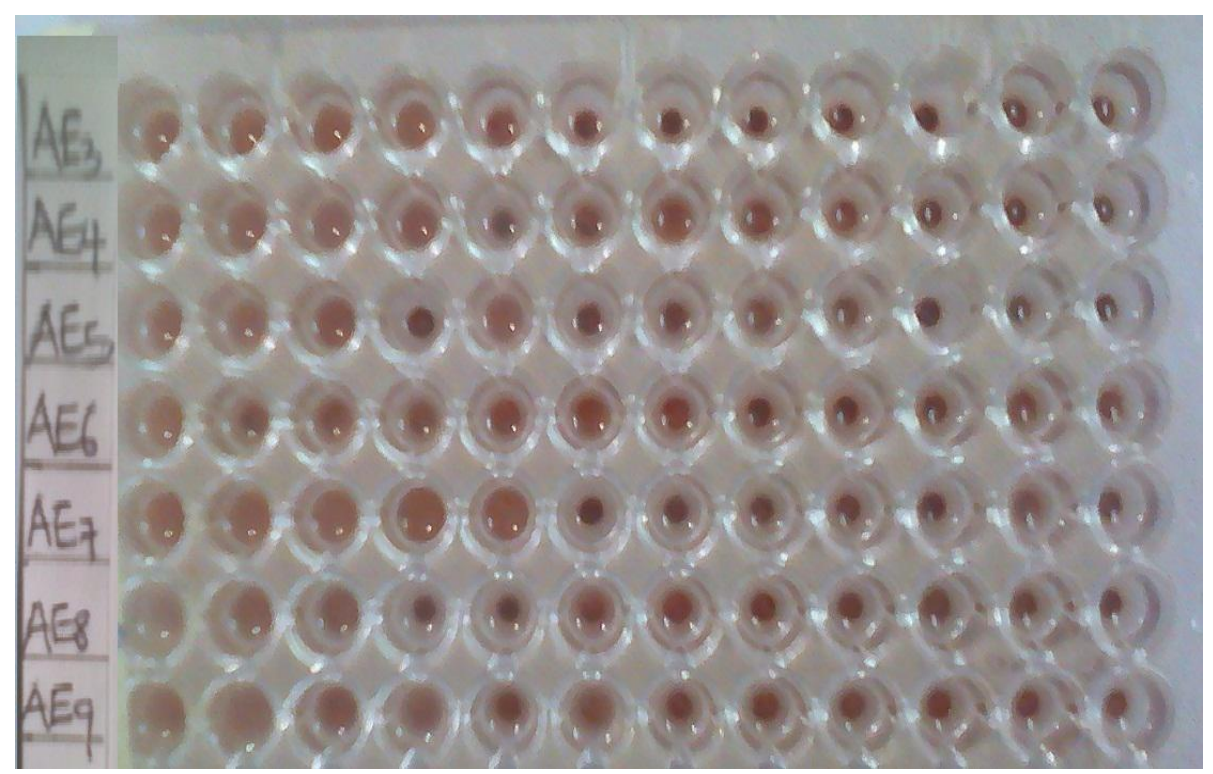

Plate 5: Hemagglutinating activity of lectin in affinity extracted from A.esculentus.

Key to plate:AE3-AE9: A.esculentus: hemaglutinating seed sample

\subsection{Protein Concentration in the samples}

Experimental results showed that A.caillei: has higher protein concentration in their leaves than A.esculentus. Also, protein concentration is high in seeds of A.esculentus than A.caillei. The variation in the protein concentration between A.esculentus and A.caillei seeds and leaves are represented in Figures 1 and 2, respectively.

Fig. 1 shows the variation of protein in leaves of the two species Abelmoschusesculentus(AEL) and Abelmoschus caillei (ACL).The distance between the peak of the line representing Abelmoschus esculentus and Abelmoschus caillei in each replicates shows that Abelmoschus caillei (ACL) contain higher protein in their leaves than Abelmoschus esculentus.

Also in fig. 2 which shows the differences between the protein present in seeds of Abelmoschus caillei and Abelmoschus esculentus. The distance between individual peak of Abelmoschus esculentus and Abelmoschus caillei shows that protein concentration present in Abelmoschus esculentus is higher than that of Abelmoschuscaillei.

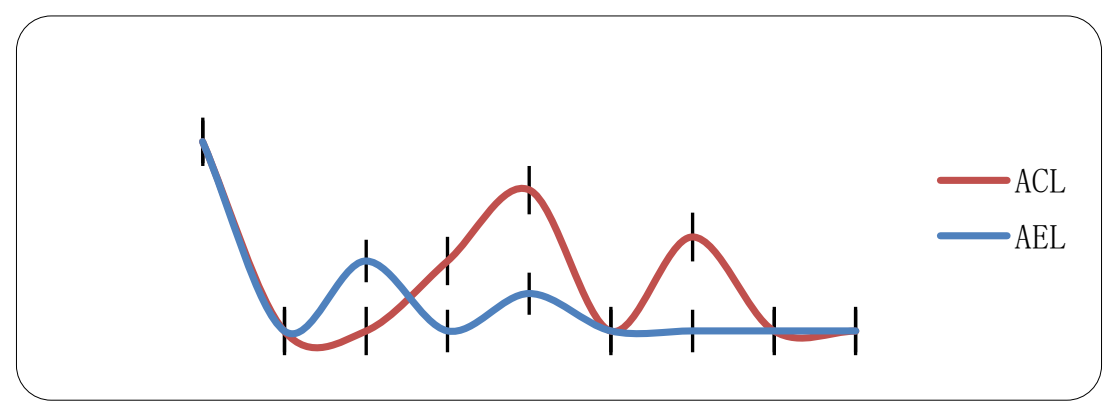

Fig. 1: Protein concentration between A. esculentus(AEL)and A. caillei(ACL) leaves. 


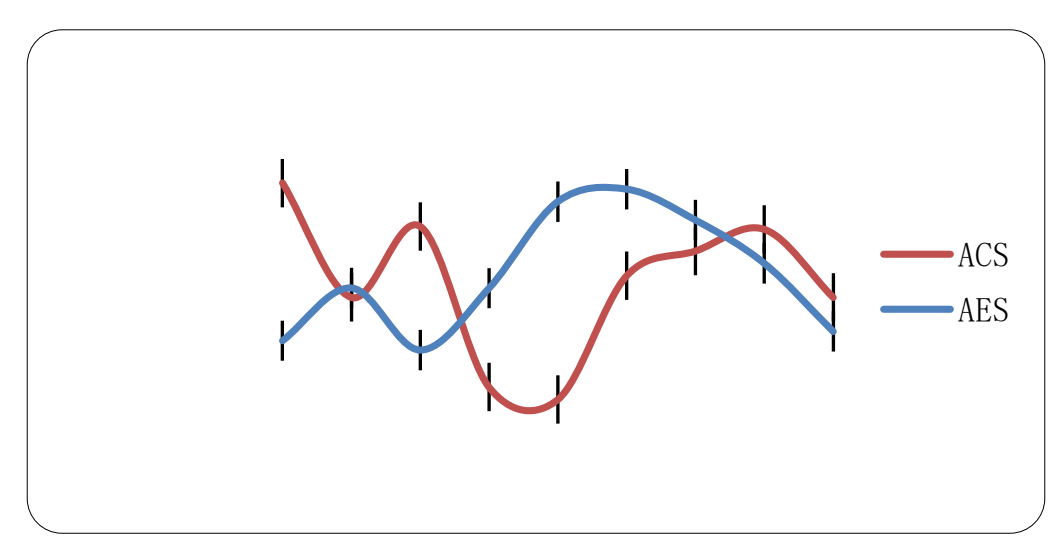

Fig.2: Protein concentration between $A$. esculentus(AES) and $A$. caillei(ACS) seeds.

\section{DISCUSSION}

Variability is particularly useful as it enhances success in selection of superior crop species. Hemagglutination of lectin extracted from A.esculentus and A.caillei $(\mathrm{Cp}(\mathrm{mg} / \mathrm{mL}))$ was used as the positive control. Negative control (N) contained buffer only. Each well of the microtiter plate contains $100 \mu \mathrm{L}$ of sample, $50 \mu \mathrm{L}$ of $2 \%$ suspension of human erythrocytes. The agglutination of samples form a carpet that covers the whole well; where no agglutination occurs, red blood cells form a button at the bottom of the well.

Control (N) showed no agglutination. All red blood cells have sedimented to the bottom of wells and formed a small button.

The agglutination assay was used qualitatively to provide evidence for the presence of lectin in isolated fractions in the leaves and seeds of A. esculentus and A.caillei and to differentiate them using the presence of lectin.

According to Johnet al. (2007) the amount of lectin present in the sample were used in differentiating two forms of beans where the lectin content was much lower in the canned samples than in the dry raw bean samples. In the Affinity extracted, the amount of lectin present was much lower in the leaves of A.caillei but high in A. esculentus and in the seeds of both above named species $A$. caillei has the highest Lectin content than A.esculentus.

Addition of Bradford reagent to the extracts from both species of A. esculentus and A. caillei indicated that the leaves of A. esculentus contain high protein concentration than A. caillei that possess low concentration of protein.

Crosses between A. caillei and A. esculentus may result to very favorable and rich specie with all in all agronomical and biochemical characteristics. The variability observed among the above named two species of okra shows that there are potential for improvement in okra.

\section{CONCLUSION AND RECOMMENDATIONS}

Variability observed in this study was indicative of the differences existing between the two species of okra considered, thus offering better chances and large scope for selection. It can be deduced from this study that it may be beneficial health wisely, to consume more of the A. esculentus because it contains high protein content than A. caillei.

Due to the high level content of lectin in the seeds of A. caillei, it is better according to the findings, to reduce drastically, the rate of the consumption of the okra species as a result of its health implications, which include inflammatory, intestinal disorder and other related diseases.

\section{REFERENCES}

- Camciuc M., M. Deplagne, G. V ilarem and A. Gas et, 1998. Okra- Abelmoschus esculentus L. (Moench.) a crop with economic potential for set aside acre age in France. Industrial Crops and Products. 7: 257-264.

- Hamid Rabia, Akbar Masood, Ishfak H. Wani, and ShaistaRafiq., Lectins: Proteins with Diverse Applications. Journal of Applied Pharmaceutical Sci. 2013; 3 (4 Suppl 1): S93-S103.

- Olayiwola MO., Ariyo OJ and Ojo DK (2014).Evaluation of genetic variability among okra genotypes Abelmoschus esculentus) L. (Moench), Journal of Plant and Pest Science, 1 (2): 66-73

- Ruby A. Ynalvez1, Carmen G. Cruz1, Marcus A. Ynalvez (2015).Isolation, Partial Purification and Characterization of Texas Live Oak (Quercus fusiformis) Lectin. Advances in Bioscience and Biotechnology.6, 470-484. 
- Rubatzky, V.E. and M. Yamaguchi, (1997).World vegetables.Principles, Production and Nutritive values.2nd Edn.Inter.ThomsonPub,New York. : 681- 686.

- John Shi, Sophia Jun Xue, Yukio Kakuda, Sanja Ili, Daniel Kim.(2007).Isolation and characterization of lectins from kidney beans (Phaseolusvulgaris). Journal of Process Biochemistry 42 (2007) 1436-1442. 